\title{
Kompetensi Guru Matematika Dalam Mengembangkan Kompetensi Matematis Siswa
}

\author{
Kurnia Putri Sepdikasari Dirgantoro \\ kurnia.dirgantoro@uph.edu \\ Universitas Pelita Harapan
}

\section{Mathematics Teacher's Competence in Developing Student's Mathematic Competence}

\begin{abstract}
Education can not be separated from two main factors; teacher and student. In the absence of either of these two factors, it is essentially not education. In Indonesia, education is still far from what is expected. This can be seen from the fact that there are difficulties of the graduates achieving decent work result in accordance with the level of education they are in. One of the causes of the low quality of education in Indonesia is because the competence of teachers as educators is still considered low when compared with the standards that have been prepared. This article will discuss the influence of teacher competence on student competence, especially in Mathematics learning.
\end{abstract}

Keywords: teacher competence, student's mathematical competence

Received date: 26 Oktober 2017

Article Info

Revised date: 6 April 2018

Accepted date: 4 Mei 2018

\section{PENDAHULUAN}

Pendidikan merupakan salah satu topik menarik yang tidak akan pernah ada habisnya untuk diperbincangkan, khususnya di Indonesia. Mulai dari timpangnya kualitas pendidikan antara daerah yang satu dengan yang lain; juga tentang Ujian Nasional (UN) yang sampai saat ini keberadaannya masih diwarnai pro dan kontra ditambah dengan pelaksanaan UN yang dinilai tidak jujur dan hanya menguntungkan beberapa pihak saja.

Beberapa tahun belakangan ini, tingkat kelulusan UN baik SD, SMP, SMA/MA dan SMK mencapai lebih dari 90 persen.Meskipun hasil ini terlihat baik, namun dengan kenyataan bahwa sulitnya lulusan SMA/MA dan SMK mendapat pekerjaan yang layak menggambarkan bahwa pendidikan di Indonesia belum mampu menghasilkan SDM (Sumber Daya Manusia) yang berkualitas dan dapat bersaing. Untuk itu, upaya meningkatkan kualitas SDM Indonesia yang memiliki kemampuan memadai untuk memenangkan berbagai persaingan perlu terus ditumbuhkembangkan (Suryadi, 2012).

Selain masalah SDM, pendidikan nasional pun dinilai masih belum maksimal dalam membangun karakter bangsa. Wahyu (2011) menyatakan bahwa "sekolah-sekolah memang melahirkan manusia cerdas, namun kurang memiliki kesadaran akan pentingnya nilai-nilai moral dan sopan santun dalam hidup bermasyarakat". Hal ini terlihat dari mengemukanya fenomena negatif saat ini, yaitu maraknya perkelahian pelajar, narkoba, korupsi, plagiarisme, kecurangan dalam ujian dan gejolak masyarakat (social unrest).

Rendahnya kualitas pendidikan di Indonesia pun nampak dari rendahnya peringkat Indonesia bila dilihat dari kancah internasional, khususnya dalam bidang matematika. Hasil studi PISA (Program for International Student Assessment) tahun 2015 menunjukkan Indonesia menduduki peringkat 69 dari 76 negara. Sedangkan dari hasil studi Trends in InternationalMathematics and Science Study (TIMSS) menempatkan Indonesia di urutan ke36 dari 49 negara. [http://www.pikiran-rakyat.com/pendidikan/2016/06/18/peringkatpendidikan-indonesia-masih-rendah-372187]. Padahal di Indonesia, matematika merupakan 
bidang studi wajib yang mengisi kurikulum pendidikan dasar hingga menengah dengan jumlah jam lebih banyak dibandingkan mata pelajaran lainnya.

Banyaknya jam pelajaran matematika yang mengisi kurikulum pendidikan di Indonesia disebabkan matematika dirasakan memiliki kontribusi yang penting bagi kehidupan peserta didik. Dengan mempelajari matematika, siswa dilatih untuk dapat berpikir logis, kritis, kreatif dan terstruktur yang pada akhirnya melalui kemampuan ini siswa dapat mengembangkan pola pikirnya, terlebih dalam pemecahan masalah. Tak dapat dipungkiri bahwa dalam hidup kesehariannya, siswa tidak akan pernah lepas dari masalah, baik dalam kehidupan pribadi maupun dalam lingkungan pekerjaannya kelak.

Hasil survey lapangan yang termuat dalam Laporan Departemen Pendidikan Amerika Serikat dalam Mathematics Equal Opportunity (Sudrajat, 2008) menyatakan bahwa kemampuan dasar matematika dirasakan sangat penting dalam dunia kerja. Pekerja tamatan sekolah menengah dengan kemampuan matematika tinggi mempunyai karir yang lebih baik dalam dunia kerja. Selain itu, tingkat pengangguran tamatan sekolah menengah dengan kemampuan matematika tinggi lebih rendah dibandingkan dengan tamatan yang kemampuan matematikanya rendah. Di Indonesia, Keputusan Menteri Tenaga Kerja dan Transmigrasi No: Kep. 244/MEN/V/2007 menyatakan bahwa kompetensi kunci yang diperlukan tenaga kerja meliputi: mengumpulkan, mengorganisir dan menganalisa informasi; mengkomunikasikan ide-ide dan informasi; merencanakan dan mengorganisir aktivitas-aktivitas; bekerja dengan orang lain dan kelompok; menggunakan ide-ide dan teknik matematika; memecahkan masalah; dan menggunakan teknologi. Artinya, matematika merupakan ilmu dasar yang dibutuhkan oleh seseorang untuk siap masuk di dalam dunia kerja profesional.

Perkembangan teknologi saat ini pun tidak lepas dari pengaruh matematika karena perkembangan matematika dan teknologi saling berkaitan satu dengan yang lain. Perkembangan dalam struktur dan penalaran matematika sering dapat diterapkan pada berbagai bidang ilmu yang lain, khususnya dalam perkembangan teknologi. Sebaliknya, perkembangan teknologi pun turut mendorong perkembangan matematika. Sudrajat (2008) menyatakan bahwa perkembangan pesat di bidang teknologi informasi dan komunikasi dewasa ini dilandasi oleh perkembangan matematika di bidang teori bilangan, aljabar, analisis, teori peluang dan matematika diskrit. Karenanya, untuk menguasai dan menciptakan teknologi di masa depan diperlukan penguasaan matematika yang kuat sejak dini.

Menilai betapa pentingnya peran matematika dalam kehidupan saat ini, maka belajar matematika dianggap menjadi suatu kebutuhan yang harus dipenuhi.Oleh karena itu, hendaknya para peserta didik dapat menganggap belajar matematika sebagai kegiatan yang menyenangkan. Namun tidaklah demikian pada kenyataannya karena anggapan bahwa belajar matematika adalah hal yang membosankan belum berubah. Matematika pun dianggap sebagai mata pelajaran yang sulit dan menakutkan (Harahap \& Syarifah, 2015). Banyak faktor yang dapat menyebabkan siswa merasa kesulitan dalam belajar matematika, yakni faktor dari dalam dan faktor dari luar diri siswa.

Ruseffendi (2006) menyatakan bahwa faktor luar yang mempengaruhi berhasil atau tidaknya siswa belajar adalah kompetensi guru, cara belajar, situasi pembelajaran dan kondisi lingkungan baik dalam arti sempit maupun luas. Situasi pembelajaran berkaitan dengan kegiatan pembelajaranyang bermakna di dalam kelas. Mawardi (2013) menjelaskan kegiatan pembelajaran akan bermakna jika dilakukan dalam lingkungan yang nyaman dan memberikan rasa aman, bersifat individual dan kontekstual, anak mengalami langsung yang dipelajarinya.

Faktor-faktor luar ini merupakan faktor yang sangat menentukan, khususnya kompetensi guru. Yohanes Surya, Pembina Tim Olimpiade Fisika Indonesia (TOFI) menyatakan bahwa rendahnya kemampuan anak didik pada mata pelajaran matematika dan sains tidak terlepas dari kemampuan guru dalam mengajarkan siswanya (Rangkuti dan 
Anggraeni, 2005). Dengan kata lain, guru mempunyai peranan besar dalam meningkatkan kualitas anak didik. Hal ini sejalan dengan pendapat Gede, R dkk (2009: 210) yang menyatakan bahwa "Tidak ada bangsa yang maju, sejahtera dan bermartabat tanpa pendidikan yang baik, dan tidak ada pendidikan yang baik tanpa guru yang baik". Oleh sebab itu, artikel ini akan membahas lebih lanjut mengenai kontribusi kompentensi guru matematika terhadap kompetensi matematis siswa dengan menggunakan pendekatan studi kepustakaan untuk memperoleh gambaran yang lebih jelas mengenai kompetensi guru dalam mengembangkan kompetensi matematis siswa. Studi kepustakaan berkaitan dengan kajian teoretis dan referensi lain yang berkaitan dengan nilai, budaya dan norma yang berkembang pada situasi sosial yang diteliti (Sugiyono, 2013).

\section{PEMBAHASAN}

Dengan teknologi yang semakin berkembang saat ini, siswa dapat memperoleh informasi tidak hanya melalui guru melainkan dari sumber belajar lain seperti modul, buku, dan internet. Walaupun demikian, faktor guru masih menentukan.Contohnya, pada sistem belajar sendiri (modul) di mana guru tidak langsung menjelaskan materi kepada siswa melainkan siswa yang aktif mengkontruksi pengetahuannya, namun peran guru di sini tetap ada. Guru tetap dapat menentukan berhasilnya siswa belajar, misalnya dalam hal bagaimana cara guru membimbing siswa belajar modul dan bagaimana sikap guru melayani siswa yang tidak mengerti sesuatu dari modul. Hal lain yang perlu diingat adalah bahwa berhasilnya seorang siswa belajar tidak hanya dilihat dari besarnya nilai yang ia peroleh, melainkan juga dari terbentuknya sikap atau pribadi yang sesuai dengan karakter bangsa dan tujuan pendidikan yang telah dirumuskan.

Pernyataan ini sejalan dengan semboyan yang dipakai oleh Bapak Pendidikan Indonesia, Ki Hajar Dewantara. Secara utuh, semboyan itu dalam bahasa Jawa berbunyi ing ngarso sung tulodo, ing madyo mangun karso, tut wuri handayani: di depan memberi contoh, di tengah memberi semangat, di belakang memberi dorongan. Ini berarti, guru tidak hanya bertugas mengajar siswa, melainkan juga mendidik, memberi motivasi dan dukungan kepada siswa agar siswa mampu berkembang dengan maksimal sesuai dengan kemampuan yang dimilikinya.

Mengingat besarnya sumbangsih guru dalam mempengaruhi kualitas pendidikan, maka usaha dalam meningkatkan kompetensi guru perlu mendapat perhatian serius. Selvi (2010) menyatakan bahwa kompetensi yang dimiliki guru memiliki pengaruh terhadap nilainilai, kebiasaan, komunikasi, tujuan dan praktek di sekolah. Ketika kompetensi guru sudah baik maka peningkatan kualitas pendidikan bukanlah hal yang tidak mungkin dapat dicapai.

\section{Guru}

Guru merupakan salah satu faktor yang tidak dapat dipisahkan dari pendidikan. Tanpa ada guru maka hakekat pendidikan tidak mungkin dapat tercapai. Pemerintah dalam Peraturan Pemerintah Republik Indonesia Nomor 74 Tahun 2008 mendefinisikan "guru adalah pendidik profesional dengan tugas utama mendidik, mengajar, membimbing, mengarahkan, melatih, menilai, dan mengevaluasi peserta didik pada pendidikan anak usia dini jalur pendidikan formal, pendidikan dasar, dan pendidikan menengah". Berdasarkan definisi tersebut dapat kita lihat bahwa guru adalah seseorang yang memiliki tugas utama dalam mendidik siswa. Mendidik sama artinya dengan mengembangkan karakter seseorang agar orang tersebut dapat berkembang menjadi pribadi yang cakap, aktif, kreatif, dan mandiri. Van Brummelen (2009) menyatakan bahwa mendidik berarti secara sengaja merangsang dan mengembangkan pemahaman, pandangan, dan kemampuan siswa.Hal ini bukanlah hal yang mudah karena untuk mendidik seorang siswa diperlukan waktu yang cukup lama dari pada hanya sekedar mengajarkan suatu pengetahuan atau keterampilan kepadanya. Slameto (2014) 
guru mempunyai peran strategis dalam bidang pendidikan, guru merupakan ujung tombak dalam upaya meningkatkan kualitas layanan dan hasil pendidikan.

Macmillan (Koswara dan Halimah, 2008) mendefinisikan guru sebagai "someone who other people respect and go to for advice abaout a particular subject". Guru adalah seorang yang dihormati dan tempat meminta nasihat untuk permasalahan-permasalah tertentu. Dari definisi tersebut dapat dilihat bahwa guru adalah profesi yang luhur dan mulia, yang begitu dihargai oleh masyarakat.Pahlawan tanpa tanda jasa, itulah yang sering disebut orang mengenai profesi guru.

Dalam pendidikan Kristiani, Van Brummelen (2009) menyatakan bahwa seorang guru adalah alat yang dipakai Tuhan untuk dapat "mengerjakan di dalam kamu baik kemauan maupun pekerjaan menurut kerelaan-Nya" supaya mereka dapat "bercahaya di antara mereka seperti bintang-bintang di dunia, sambil berpegang pada Firman kehidupan" (Filipi 2: 13, 15, 16). Artinya guru adalah alat yang dipakai Tuhan untuk dapat menjadi berkat bagi dunia pendidikan di mana mereka dipanggil Tuhan untuk melayaniNya.

\section{Peran Guru}

Guru sebagai pendidik memiliki tugas untuk mengalihkan pengetahuan dan keterampilan kepada peserta didik agar mereka mampu menyerap, menilai, dan mengembangkan secara mandiri ilmu-ilmu yang dipelajarinya. Koswara dan Halimah (2008) menyatakan bahwa secara umum guru memiliki lima peran, yaitu sebagai komunikator, fasilitator, motivator, administrator dan konselor. Berikut akan diuraikan mengenai peranperan tersebut, khususnya bagi guru matematika.

1. Komunikator, yaitu mengajarkan ilmu dan keterampilan kepada peserta didik.

Sampai saat ini anggapan bahwa matematika adalah pelajaran yang sulit dan hanya berisi rumus-rumus yang dihafalkan masih banyak melekat di benak siswa. Anggapan ini mungkin saja terjadi karena kesalahan guru dalam mengkomunikasikan konsep, struktur, teorema atau rumus kepada siswa. Seorang guru matematika yang baik perlu menguasai kemampuan komunikasi, baik lisan ataupun tulisan agar siswa lebih mudah memahami konsep yang dipelajari dan agar konsep itu benar-benar bermakna bagi mereka.

2. Fasilitator, yaitu sebagai pelancar proses belajar.

Sebagai fasilitator, guru matematika hendaknya mampu mengusahakan berbagai sumber belajar yang berguna dan dapat menunjang pencapaian tujuan dan proses belajar mengajar, baik berupa narasumber, buku teks, alat peraga, majalah, ataupun surat kabar. Guru perlu memastikan siswa agar memperoleh informasi dan pengetahuan, baik melalui penjelasan, kegiatan yang dirancang, atau melalui sumber lain yang telah guru rekomendasikan.

Hal-hal yang perlu diperhatikan dalam menentukan media/alat/bahan/sumber belajar antara lain: daya tarik dan minat peserta didik, merangsang tumbuhnya pengertian, sederhana dari segi bahan/harga/ketersediannya, memperhatikan tingkat kematangan berpikir dan usia peserta didik, kesesuaian dengan bahan ajar, pendekatan atau strategi pembelajaran yang digunakan. Melalui pemilihan sumber belajar yang tepat maka guru dapat lebih memudahkan siswa memahami konsep-konsep matematika yang diberikan.

3. Motivator, yaitu menumbuhkan minat dan semangat belajar peserta didik secara terusmenerus.

Pada dasarnya setiap siswa memiliki kemampuan untuk memotivasi diri sendiri (intrinsic motivation), sehingga ada ataupun tidak adanya stimuli tetap saja akan termotivasi. Hanya saja, kadar motivasi dari diri sendiri sering tidak stabil kehadirannya. Untuk itulah maka motivasi dari luar dirinya (extrinsic motivation) tetap sangat diperlukan. Di sinilah seorang guru dapat mengambil peran. Dengan kesan bahwa matematika adalah mata pelajaran yang sulit, seringkali siswa sudah merasa malas untuk belajar matematika. Di 
sinilah guru perlu memberi motivasi lewat kata-kata, cerita ataupun tindakan yang dapat memberikan siswa motivasi untuk terus mau belajar matematika. Dengan adanya usaha yang tekun dari siswa dan motivasi terus menerus dari guru, maka siswa dapat memiliki prestasi yang baik.

4. Administrator, yaitu melaksanakan tugas-tugas bersifat administratif, seperti administrasi kelas.

Sebelum melaksanakan proses pembelajaran, guru perlu membuat administrasi kelas, yaitu berupa rencana pembelajaran agar pembelajaran berlangsung secara interaktif, inspiratif, menyenangkan, menantang, memotivasi peserta didik untuk berpartisipasi aktif serta memberikan ruang yang cukup bagi prakarsa, kreativitas dan kemandirian sesuai bakat, minat dan perkembangan fisik serta psikologis peserta didik.

Penyusunan rencana pembelajaran yang matang akan mempermudah, memperlancar dan meningkatkan hasil dari proses pembelajaran dan juga mempermudah guru dalam melihat, mengamati, menganalisis dan memprediksi proses pembelajaran dengan lebih terencana. Fungsi dari rencana pembelajaran yang telah disusun adalah sebagai rujukan bagi guru untuk melaksanakan pembelajaran agar lebih terarah dan terencana sehingga proses pembelajaran akan berlangsung secara efektif dan efisien.

5. Konselor, yaitu membimbing peserta didik yang mengalami kesulitan, khususnya dalam belajar.

Sehubungan dengan perannya sebagai konselor maka guru perlu memahami dan mengenal anak didiknya dengan baik sehingga ia dapat mengetahui kesulitan apa yang dihadapi oleh peserta didik, khususnya dalam belajar karena biasanya kesulitan belajar yang dihadapi oleh para siswa itu berbeda-beda. Dalam hal ini, hendaknya guru matematika menguasai berbagai macam strategi untuk menjelaskan konsep-konsep matematika agar ketika siswa tidak mengerti saat dijelaskan dengan suatu cara maka guru dapat menggunakan cara lain yang dapat lebih mudah dipahami oleh siswa.

\section{Kompetensi Guru}

Kompetensi guru merupakan seperangkat pengetahuan, keterampilan, dan perilaku yang harus dimiliki, dihayati, dikuasai, dan diaktualisasikan oleh guru dalam melaksanakan tugas keprofesionalan (Peraturan Pemerintah Republik Indonesia Nomor 74 Tahun 2008). Kompetensi guru yang dimaksud meliputi kompetensi pedagogik, kompetensi kepribadian, kompetensi sosial dan kompetensi profesional. Keempat kompetensi ini bersifat holistik, artinya guru tidak hanya dituntut untuk memiliki salah satu atau beberapa kompetensi tersebut melainkan guru dituntut untuk mampu memiliki keempat kompetensi tersebut.

1. Kompetensi pedagogik merupakan kemampuan yang berkenaan dengan pemahaman terhadap siswa dan pengelolaan pembelajaran yang mendidik dan dialogis. Kompetensi pedagogik secara umum menuntut guru untuk mampu mengelola pembelajaran yang mencakup pemahaman dan pengembangan peserta didik; serta perencanaan, pelaksanaan dan evaluasi kegiatan pembelajaran.

2. Kompetensi kepribadian menuntut kepribadian guru yang mantap, stabil, dewasa, arif dan berwibawa, menjadi teladan bagi peserta didik, dan berakhlak mulia. Ketika siswa melihat gurunya sebagai pribadi yang bersahaja dengan tutur kata dan perbuatan yang baik, maka siswa dapat melihat guru sebagai pribadi yang dapat dicontoh dan dijadikan panutan sehingga tujuan pendidikan untuk menghasilkan siswa yang sesuai dengan karakter bangsa dapat terwujud.

3. Kompetensi sosial adalah kemampuan guru dalam berkomunikasi dan berinteraksi secara efektif dengan siswa, sesama guru, tenaga kependidikan, orang tua/wali siswa dan masyarakat. 
4. Kompetensi profesional adalah kemampuan guru dalam penguasaan materi pembelajaran secara luas dan mendalam yang memungkinkannya membimbing siswa memperoleh kompetensi yang ditetapkan.

Sebagai pembanding, badan National Board for Professional Teaching Skill pada tahun 2002 di Amerika (Koswara dan Halimah, 2008) merumuskan standar kompetensi bagi guru Amerika sebagai dasar untuk memperoleh sertifikasi guru. Standar kompetensi ini dirumuskan sebagai What Teachers Should Know and Be Able to Do yang terdiri atas lima proposisi utama, yaitu sebagai berikut.

1. Teachers are Committed to Students and Their Learning, yang mencakup: penghargaan guru terhadap individual siswa, (b) pemahaman guru terhadap perkembangan belajar siswa, (c) perlakuan guru terhadap seluruh siswa secara adil, dan (d) misi guru dalam memperluas cakrawala berpikir siswa.

2. Teachers Know the Subjects They Teach and How to Teach Those Subjects to Students yang mencakup: (a) apresiasi guru terhadap pemahaman materi mata pelajaran untuk dikreasikan, disusun dan dihubungkan dengan mata pelajaran lain, (b) kemampuan guru untuk menyampaikan materi pelajaran, dan $\quad$ (c) mengembangkan usaha untuk memperoleh pengetahuan dengan berbagai cara (multiple path).

3. Teachers are Responsible for Managing and Monitoring Student Learning yang mencakup: (a) penggunaan berbagai metode dalam pencapaian tujuan pembelajaran, (b) menyusun proses pembelajaran dalam berbagai setting kelompok (group setting), (c) kemampuan untuk memberikan ganjaran (reward) atas keberhasilan siswa, (d) menilai kemajuan siswa secara teratur, dan (e) kesadaran akan tujuan utama pembelajaran.

4. Teachers Think Systematically about Their Practice and Learn from Experience yang mencakup: (a) guru secara terus menerus menguji diri untuk memilih keputusan keputusan terbaik dan (b) guru meminta saran dari pihak lain dan melakukan berbagai riset tentang pendidikan untuk meningkatkan praktek pembelajaran.

5. Teachers are Members of Learning Communities yang mencakup: (a) guru memberikan kontribusi terhadap efektivitas sekolah melalui kolaborasi dengan kalangan profesional lainnya, (b) guru bekerja sama dengan orangtua siswa, dan (c) guru dapat menarik keuntungan berbagai sumber daya masyarakat.

Dari kedua pendapat di atas dapat kita simpulkan bahwa untuk menjadi seorang guru, tidak hanya diperlukan kecerdasan secara kognitif, melainkan juga kecerdasan emosional dan sosial.

\section{Kompetensi Guru Matematika}

Guru matematika perlu memiliki empat kompetensi seperti yang telah disebutkan di atas agar dapat mengelola pembelajaran matematika dengan baik.

1. Kompetensi pedagogik. Seorang guru matematika perlu memiliki pemahaman mengenai siswanya dalam pembelajaran matematika. Apakah siswa memiliki minat serta apa yang kelemahan dan kesulitan dasar yang dialami siswa dalam matematika. Pemahaman mengenai tahap perkembangan siswa pun perlu dipahami guru. Dengan pengetahuan dan pemahaman akan hal-hal tersebut, maka guru dapat memilih dan menerapkan strategi pembelajaran yang tepat, yang dapat membantu dan memotivasi siswa dalam belajar matematika. Dalam pembelajaran matematika, guru yang memiliki kompetensi pedagogik yang baik dapat menyusun kegiatan pembelajaran yang mampu memudahkan siswa dalam mempelajari matematika.

2. Kompetensi kepribadian. Seorang guru matematika perlu menjadi panutan dan teladan siswa dalam hal sikap dan tutur kata. Selama ini, anggapan yang berkembang mengenai 
guru matematika adalah seorang yang galak, kasar dan bermulut tajam. Anggapan ini perlu diubah melalui sikap dan tutur kata guru matematika selama melaksanakan pembelajaran di kelas. Seorang guru matematika perlu memiliki kesabaran dan pengendalian diri yang baik dalam kelas khususnya ketika menemukan siswa yang kurang mampu dalam matematika. Konsep bahwa siswa pun adalah gambar dan rupa Allah perlu diingat sehingga guru dapat menghargai siswa dan memperlakukan siswa sebagaimana layaknya.

3. Kompetensi sosial. Guru matematika perlu memiliki kemampuan komunikasi yang baik dengan siswa, sesama guru, tenaga kependidikan, orang tua/wali siswa dan masyarakat. Guru matematika perlu memiliki telinga dan hati yang terbuka, khususnya dalam mendengarkan saran dan kritik untuk perbaikan dalam pembelajarannya. Ketika siswa datang ke kelas dalam keadaan yang kurang siap untuk belajar, guru perlu mencoba untuk mendengarkan siswa, apakah ada alasan yang mendasar yang menyebabkan hal tersebut. Dengan memiliki kompetensi sosial yang baik maka guru dapat melaksanakan kegiatan pembelajaran yang menyenangkan.

4. Kompetensi profesional. Kompetensi khusus yang pelu dimiliki oleh setiap guru matematika, adalah:(1) menggunakan bilangan, hubungan di antara bilangan, berbagai sistem bilangan dan teori bilangan; (2) menggunakan pengukuran dan penaksiran; (3) menggunakan logika matematika; (4) menggunakan konsep-konsep geometri; (5) menggunakan konsep-konsep statistika dan peluang; (6) menggunakan pola dan fungsi; (7) menggunakan konsep-konsep aljabar; (8) menggunakan konsep-konsep kalkulus dan geometri analitik; (9) menggunakan konsep dan proses matematika diskrit; (10) menggunakan trigonometri; (11) menggunakan vektor dan matriks; (12) menjelaskan sejarah dan filsafat matematika; serta (13) mampu menggunakan alat peraga, alat ukur, alat hitung, piranti lunak komputer, model matematika, dan model statistika. Kompetensi di atas secara umum menuntut guru matematika untuk mampu menguasai seluruh materi matematika di tingkat sekolah menengah agar guru dapat membimbing siswa memahami materi-materi tersebut. Untuk itu, guru perlu mengemasnya menjadi sesuatu yang menarik untuk dipelajari. Guru dapat mengembangkan pertanyaan-pertanyaan yang dapat merangsang siswa untuk berpikir dan berlatih dalam proses pemecahan masalah. Pertanyaan guru itu hendaknya bersifat terbuka dan mengarah pada investigasi serta bersifat divergen, tidak simple, open-ended dan merangsang siswa untuk belajar dengan bekerjasama. Selain hal-hal tersebut, seorang guru matematika pun perlu mempunyai kemampuan komunikasi matematis, baik lisan maupun tertulis; kemampuan penalaran; pembuktian; representasi matematis dan pemecahan masalah.Kemampuan-kemampuan ini merupakan kemampuan yang pada akhirnya dituntut untuk dimiliki siswa. Untuk itu, sebagai seseorang yang akan membantu siswa mempelajari seluruh kemampuan tersebut maka guru matematika juga idealnya telah menguasai kemampuan tersebut agar ia tidak mengalami kesulitan ketika mengajarkan kemampuan-kemampuan tersebut kepada para siwanya. Jika guru tidak menguasai kemampuan-kemampuan ini maka bagaimana ia dapat mengajarkannya kepada siswa. Sejalan dengan berbagai pendapat di atas, Niss \& $\mathrm{H} \varnothing$ jgaard (2011) menyatakan bahwa seorang guru matematika perlu memiliki (1) mathematical thinking competency, (2) problem tackling competency, (3) modelling competency, (4) reasoning competency, (5) representing competency, (6) symbol and formalism competency, (7) communicating competency, dan (8) aids and tools competency. Sumarmo (2013) juga berpendapat bahwa guru matematika hendaknya menguasai pengalaman belajarnya terdahulu yang kemudian diperlengkapi untuk dapat diteruskan kepada siswa, menguasai proses berpikir matematika, menguasai pendekatan dan metode pembelajaran yang sesuai sehingga melalui semuanya itu dapat mendukung siswa untuk mengembangkan kemampuan berpikir kritis, menggunakan nalar secara 
efektif dan efisien, serta menumbuhkan sikap ilmiah, disiplin, bertanggung jawab, keteladanan dan rasa percaya diri.

\section{Kompetensi Matematis Siswa}

Dalam Kurikulum Nasional disebutkan bahwa kecakapan atau kemahiran matematika yang diharapkan dapat tercapai dalam belajar matematika mulai SD/MI hingga SMA/MA, adalah sebagai berikut.

1. Memahami konsep matematika, menjelaskan keterkaitan antara konsep dan mengimplikasikan konsep atau algoritma, secara luwes, akurat, efisien dan tepat dalam pemecahan masalah.

2. Menggunakan penalaran pada pola dan sifat, melakukan manipulasi matematika dalam membuat generalisasi, menyusun bukti, atau menjelaskan gagasan dan pengetahuan matematika.

3. Memecahkan masalah yang meliputi kemampuan memahami masalah, merancang model matematika, menyelesaikan model, dan menafsirkan solusi yang diperoleh.

4. Mengkomunikasikan gagasan dengan simbol, tabel, diagram, atau media lain untuk memperjelas keadaan atau masalah.

5. Memiliki sikap menghargai kegunaan matematika dalam kehidupan, yaitu memiliki rasa ingin tahu, perhatian dan minat dalam mempelajari matematika, serta sikap ulet dan percaya diri dalam pemecahan masalah.

Kelima kompetensi tersebut saling berkaitan satu dengan yang lain, dan kesemuanya sama penting sehingga diharapkan kelima kompetensi tersebut dapat dikembangkan secara bersama-sama. Siswa yang memiliki pemahaman konsep dan penalaran yang baik akan dapat memecahkan masalah dan mengkomunikasikan ide mereka dengan tepat. Dan ketika siswa memiliki sikap menghargai kegunaan matematika dalam kehidupan maka siswa pun dapat melihat bagaimana matematika dapat digunakan dalam memecahkan masalah sehari-hari. Dalam mengembangkan kelima kompetensi tersebut, secara tidak langsung siswa dilatih untuk dapat berpikir logis, kritis, kreatif dan terstruktur yang pada akhirnya dapat mengembangkan pola pikirnya. Pembelajaran matematika yang ideal diharapkan mampu membimbing siswa untuk dapat memiliki kemampuan berpikir matematis juga untuk mengembangkan kemampuan dan keterampilan matematika mereka agar mampu menerapkan pola pikir matematika dalam kehidupan sehari-hari dan dalam mempelajari ilmu pengetahuan yang lain.

\section{Pengaruh Kompetensi Guru Matematika terhadap Kompetensi Siswa}

Penelitian tentang pengaruh kompetensi guru matematika terhadap kompetensi siswa telah banyak dilakukan. Berikut akan dibahas beberapa penelitian yang relevan.

1. Gürsel Güler danAlper Çiltaş pada tahun 2011 meneliti tentang tingkat penggunaan representasi guru matematika terhadap tingkat penggunaan representasi siswa dalam memecahkan masalah verbal (soal cerita matematika). Dari penelitian ini diperoleh hasil sebagai berikut.

- Adanya hubungan positif antara tingkat penggunaan representasi visual guru dan siswa dalam memecahkan masalah verbal. Semakin tinggi tingkat penggunaan representasi visual guru maka semakin tinggi pula tingkat penggunaan representasi visual siswa dalam memecahkan masalah yang serupa.

- Adanya hubungan antara tingkat penggunaan representasi visual guru dengan tingkat pemecahan masalah siswa. Semakin tinggi tingkat penggunaan representasi visual guru maka semakin tinggi pula keberhasilan siswa dalam pemecahan masalah. 
2. Hill, Rowan dan Ball pada tahun 2005 meneliti tentang pengaruh pengetahuan matematis guru dalam mengajar pada pencapaian siswa. Dalam penelitian ini diperoleh hasil sebagai berikut.

- Pengetahuan matematis guru memainkan peran penting pada pembelajaran matematika, khususnya pada pembelajaran yang sangat dasar, yaitu di tingkat taman kanak-kanak dan awal sekolah dasar.

- Pengetahuan dalam mengajar yang diperlukan guru matematika tidak sebatas kemahiran menghitung melainkan juga keterampilan dalam menjelaskan dan merepresentasikan konsep matematika, serta berinteraksi dengan pemikiran matematis siswa (students' mathematical thinking). Pengetahuan guru dalam hal ini memberikan dampak pada keluaran siswa (students outcomes).

Hasil penelitian-penelitian tersebut mengemukakan bahwa kompetensi guru matematika memiliki pengaruh pada pencapaian kompetensi matematis siswa. Penguasaan guru terhadap materi, teknik pembelajaran, tenik komunikasi serta kepribadian guru memberi sumbangsih yang besar dalam perkembangan siswa. Untuk itu, peningkatan kompetensi guru perlu menjadi perhatian serius.Guru-guru, khususnya calon guru perlu memberi perhatian yang lebih terhadap pengembangan kompetensinya agar pencapaian kompetensi matematis siswa dapat terus ditingkatkan. Jika hal ini dapat dicapai maka keinginan untuk mencapai kualitas pendidikan yang baik bukanlah hanya sekedar angan-angan melainkan dapat diwujudkan.

\section{DAFTAR PUSTAKA}

Gede, R dkk.(2009). Pendidikan Karakter di Sekolah. Jakarta: Gramedia.

Güler, G. danÇiltaş, A. (2011).The Visual Representation Usage Levels of Mathematics Teachers and Students in Solving Verbal Problems. International Jounal of Humanities and Social Science, 1 (11), 145-154.

Harahap, D. H. \& Syarifah, R. (2015). Studi kasus kesulitan belajar matematika pada remaja. Jurnal Psikologi, 11, 20-30.

Hill, H. C., Rowan, B. dan Ball, D. L. (2005). Effects of Teachers' Mathematical Knowledge for Teaching on Student Achievement. American Educational Research Joutrnal Summer 2005, 42 (2), 371-406.

Koswara, D.D. dan Halimah.(2008). Bagaimana Menjadi Guru Kreatif? Bandung: PT Pribumi Mekar.

Mawardi, M. (2014). Pemberlakuan Kurikulum Sd/Mi Tahun 2013 Dan Implikasinya Terhadap Upaya Memperbaiki Proses Pembelajaran Melalui PTK. Scholaria: Jurnal Pendidikan dan Kebudayaan, 4(3), 107-121.

Menteri Tenaga Kerja dan Transmigrasi Republik Indonesia. (2007). Keputusan Menteri Tenaga Kerja dan Transmigrasi Republik Indonesia Nomor: Kep. 244.MEN/V/2007. Tersedia: http://www.Ispmigas.com/standar/Boiler.pdf.

Niss \& HØjgaard (2011).Competencies and Mathematical Learning. Denmark: Roskilde University.

Rangkuti, A. F. dan Anggraeni, F. D. (2005). Hubungan Persepsi tentang Kompetensi Profesional Guru Matematika dengan Motivasi Belajar Matematika pada Siswa SMA. Jurnal Psikologia, 1 (2), 76-85. 
Kompetensi Guru Matematika Dalam Mengembangkan Kompetensi Matematis Siswa (Kurnia Putri Sepdikasari Dirgantoro)

Ruseffendi, E. T. (2006). Pengantar kepada Membantu Guru Mengembangkan Kompetensinya dalam Pengajaran Matematika untuk Meningkatkan CBSA. Bandung: Tarsito.

Selvi, Kiymet. (2010). Teachers' Competencies.Cultura International Journal of Philosophy of Culture and Axiology. Volume 7, Issue 1, 2010.

Slameto, S. (2014). Permasalahan-Permasalahan Terkait Dengan Profesi Guru SD. Scholaria: Jurnal Pendidikan dan Kebudayaan, 4(3), 1-12.

Sudrajat.(2008). Peranan Matematika dalam Perkembangan Ilmu Pengetahuan dan Teknologi. Tersedia: http://pustaka.unpad.ac.id/wpcontent/uploads/2010/08/peranan_matematika_dlm_perkembangan_iptek.pdf (5 Januari 2018)

Sugiyono. (2013). Metode Penelitian Kuantitatif Kualitatif dan R\&D. Bandung: Alfabeta.

Sumarmo, U. (2013). Kumpulan Makalah Berpikir dan Disposisi Matematika Serta Pembelajarannya. Bandung: Universitas Pendidikan Indonesia.

Suryadi, D. (2012). Membangun Budaya Baru dalam Berpikir Matematika. Bandung: Rizqi Press.

Van Brummelen, H. (2009). Berjalan dengan Tuhan di dalam Kelas. Tangerang: UPH Press.

Wahyu. (2011). Masalah dan Usaha Membangun Karakter Bangsa. Jurnal Komunitas, 3 (2), $138-149$.

http://www.pikiran-rakyat.com/pendidikan/2016/06/18/peringkat-pendidikan-indonesiamasih-rendah-372187 